\title{
Konseling Behavioral: Solusi Alternatif Mengatasi Bullying Anak Di Sekolah
}

\author{
Amin Nasir \\ IAIN Kudus, Jawa Tengah, Indonesia \\ Aminnasir93@gmail.com
}

\begin{abstract}
Abstrak
Salah satu fenomena yang menyita perhatian di dunia pendidikan zaman sekarang adalah bullying di sekolah, baik yang dilakukan oleh guru terhadap siswa, maupun oleh siswa terhadap siswa lainya. Padahal semua orang tua menginginkan anak-anak mereka aman di sekolah, dan semua pendidik dan penyelenggara pendidikan juga ingin menyediakan lingkungan sekolah yang aman bagi anakanak yang belajar di sekolah tersebut. Bullying di sekolah merupakan perilaku bermasalah di kalangan remaja, yang sangat berpengaruh terhadap prestasi sekolah, keterampilan prososial, dan kesejahteraan psikologis bagi korban dan pelaku. Oleh karena itu diperlukan alternative solusi untuk mengatasi bullying anak di sekolah dengan konseling behavioral. Konseling behavioral membantu anak untuk belajar memecahkan masalah interpersonal, emosional dan kepentingan tertentu.
\end{abstract}

Kata Kunci: bullying, solusi alternatif, konseling behavioral

\begin{abstract}
One phenomenon that has caught the attention of the world of education today is bullying in schools, both those carried out by teachers and students, as well as by students towards other students. Even though all parents want their children to be safe at school, and all educators and administrators also want to provide a safe school environment for children who study at the school. Bullying in schools is problematic behavior among adolescents, which greatly influences school performance, prosocial skills, and psychological well-being for victims and perpetrators. Therefore an alternative solution is needed to overcome child bullying in schools with behavioral
\end{abstract}




\section{Konseling Behavioral: Solusi Alternatif Mengatasi Bullying ...}

counseling. Behavioral counseling helps children to learn to solve certain interpersonal, emotional and interest problems.

Keyword: bullying, alternative solution, behavioral counseling

\section{Pendahuluan}

Maraknya kasus kekerasan di sekolah makin sering ditemui baik melalui informasi di media cetak maupun yang kita saksikan di layar televisi. Selain tawuran antar pelajar sebenarnya ada bentukbentuk perilaku agresif atau kekerasan yang mungkin sudah lama terjadi di sekolah-sekolah, namun tidak mendapat perhatian, bahkan mungkin tidak dianggap sesuatu hal yang serius. Misalnya bentuk intimidasi dari teman-teman atau pemalakan, pengucilan diri dari temannya, sehingga anak menjadi malas pergi ke sekolah karena merasa terancam dan takut yang pada perkembangannya akan mempengaruhi psikologis siswa, anak menjadi depresi tahap ringan dan tentnya akan berakibat pada hasil belajar di kelas.

Pada umumnya para orang tua, guru dan masyarakat menganggap fenomena Bullying di sekolah adalah hal biasa dan baru meresponnya jika hal itu telah membuat korban terluka hingga membutuhkan bantuan medis dalam hal Bullying fisik. Sementara Bullying sosial, verbal dan elektronik masih belum ditanggapi dengan baik. Hal ini dikarenakan kurangnya pemahaman akan dampak buruk dari Bullying terhadap perkembangan dan prestasi anak di sekolah dan belum dikembangkanya system anti Bullying di sekolah. Selain itu anak-anak juga masih jarang diberikan pemahaman tentang Bullying dan dampaknya.

Kekerasan yang dialami siswa di sekolah akan menimbulkan beberapa efek negatif, seperti meningkatnya tingkat depresi, penurunan nilai-nilai akademik, bahkan dapat berhujung dengan tindakan bunuh diri. Lebih mengkhawatirkan lagi, seorang anak (pelaku) bullying lebih berpotensi untuk tumbuh sebagai pelaku kriminal dibanding yang tidak melakukan bullying. Sejumlah fakta empiris mengenai fenomena bullying di sekolah terkait dengan masalah psikologis, mengisyaratkan perlunya bentuk penanganan yang nyata terhadap para pelaku bullying. Bullying merupakan permasalahan yang terjadi dalam lingkungan sosial secara 
keseluruhan. Para remaja rentan untuk terlibat dalam situasi bullying.

Salah satu contoh kasus Bullying di sekolah terjadi di SD Gebog Kudus Jawa Tengah seorang siswi berumur 8 tahun masih duduk di kelas IV menjadi korban Bullying oleh teman-teman sekelasnya sejak kelas III, sehingga saat ini korban pindah sekolah karena trauma sering dipukul, diinjak-injak bahkan yang lebih memprihatinkan kemaluan korban dimasukkan penggaris besi hanya karena korban tidak mau menuruti keinginan mereka.(Sigit Kurniawan 2017). Perilaku Bullying seperti ini dapat menghancurkan semangat dan motivasi siswa dan membuat situasi yang tidak nyaman untuk belajar di sekolah. sekolah bukan lagi tempat yang menyenangkan bagi siswa, tetapi justru menjadi tempat yang menakutkan dan membuat trauma.

Komisi Perlindungan Anak Indonesia (KPAI) menerima 26 ribu kasus anak dalam kurun 2011 hingga september 2017. Laporan tertinggi yang diterima KPAI adalah anak yang berhadapan dengan hokum. Menurut data survey,sebanyak 84 persen anak usia 12 tahun hingga 17 tahun pernah menjadi korban Bullying (Davit Setyawan 2017).

Sekolah sebagai wadah pencetak sumberdaya manusia yang diharapkan mampu melanjutkan estafet pembangunan bangsa, proses yang terjadi didalamnya justru berisi penyiksaan dan kekerasan. Permasalahan bullying menjadi menarik untuk dibahas karena kekhawatiran diatas sehingga perlu dicarikan jalan keluar atau upaya mengatasinya. Terkait dengan upaya mengatasi permasalahan bullying dalam dunia pendidikan, konselor sebagai salah satu tenaga pendidik di sekolah dapat memainkan perannya. Selama ini beberapa upaya telah dilakukan oleh pihak sekolah bagi pelaku Bullying dengan memberikan hukuman/sanksi dan panggilan orang tua ke sekolah untuk bekerja sama memberikan penanganan. Namun, sejauh ini hasil yang dicapai belum maksimal, karena tidak disertai dengan perubahan perilaku dan sikap pelaku Bullying.

Dari latar belakang tersebut, penulis mencoba untuk menggunakan konseling behavioral untuk mengatasi Bullying pada anak di sekolah. Sejalan dengan pendekatan yang digunakan dalam penulisan ini, konseling behavioral menaruh perhatian pada upaya 


\section{Konseling Behavioral: Solusi Alternatif Mengatasi Bullying ...}

perubahan perilaku-perilaku dibentuk berdasarkan hasil dari segenap pengalamannya berupa interaksi individu dengan lingkungan sekitarnya (Latipun 2003:106). Dan secara khusus, tujuan dari konseling behavioral adalah mengubah perilaku salah dalam penyesuaian dengan cara memperkuat perilaku yang diharapkan dan meniadakan perilaku yang tidak diharapkan, serta membantu menemukan cara-cara berperilaku yang tepat.

\section{E. Pembahasan}

\section{Pengertian Bullying}

Kata bullying berasal dari Bahasa Inggris yaitu "bully" yang artinya menggertak atau menggangu. Dalam Bahasa Indonesia, secara etimologi kata bully berarti penggertak, orang yang mengganggu orang lemah. Sejiwa yang menyatakan bahwa bullying adalah situasi dimana seseorang yang kuat (bisa secara fisik maupun mental) menekan, memojokkan, melecehkan, menyakiti seseorang yang lemah dengan sengaja dan berulang-ulang, untuk menunjukkan kekuasaannya. Dalam hal ini sang korban tidak mampu membela atau mempertahankan dirinya sendiri karena lemah secara fisik atau mental (Sejiwa 2008:1).

Coloroso Barbara menyatakan bahwa "Bullying merupakan aktivitas sadar, disengaja, dan bertujuan untuk melukai, menanamkan ketakutan melalui ancaman agresi lebih lanjut, dan menciptakan teror yang didasari oleh ketidak seimbangan kekuatan, niat untuk mencederai, ancaman agresi lebih, teror yang dapat terjadi jika penindasan peningkatan tanpa henti" (Coloroso, Barbara, 2007:92).

Menurut Ken Rigby, Bullying adalah sebuah hasrat untuk menyakiti orang lain. Aksi ini dilakukan secara langsung oleh seseorang atau kelompok yang lebih kuat, tidak bertanggung jawab, biasanya berulang dan dilakukan dengan senang (Ponny Retno Astuti, 2008:3).

Coloroso membagi bullying menjadi menjadi tiga bentuk umum yaitu verbal, fisik dan relasional. Bullying secara verbal, merupakan bentuk bullying yang sering terjadi dan paling mudah dilakukan. Bentuk bullying secara verbal meliputi memanggil dengan panggilan tertentu yang memiliki asosiasi negatif, misalnya si 
pincang, si cacat, mengambil benda (uang, makanan), menghina, mengeluarkan kata-kata yang sifatnya rasis. Bullying secara fisik merupakan bentuk bullying yang mudah untuk dideteksi dan kasat mata. Hal ini meliputi memukul, menampar, menendang, mencekik, dan lain-lain. Bullying relasional adalah pelemahan harga diri korban yang dilakukan melalui pengabaian. Bentuk bullying ini sukar dideteksi. Sifat bullying ini adalah menghilangkan kepercayaan diri orang dengan cara menjauhkan individu dengan kelompok permainan, menganggap ketidak beradaan korban dalam lingkungan pergaulan dan menyebarkan gosip tentang korban (Coloroso, Barbara, 2007:47).

Bullying memiliki dampak fisik dan psikologis, secara fisik Sullivan menjelaskan bahwa perilaku bullying diantaranya adalah dampak yang mengakibatkan sakit secara fisik seperti patah tulang,gigi rusak, gegar otak, luka dimata bahkan kerusakan otak permanen. Perilaku bullying yangdirasakan oleh korban akan memberikan dampak yang tidak baik bagi perkembangan korban. Ketika siswa menjadi korban bullying mengakui bahwa mereka sangat terganggu dengan perlakuan bullying (Sullivan, 2002:27). Dampak psikologis bullying adalah harga diri, dikucilkan, ketidakhadiran, reaksi Emosional, efek domino, dampak dalam pendidikan dan bunuh diri.

\section{Jenis Bullying}

Bullying juga terjadi dalam beberapa bentuk tindakan. Menurut Coloroso, bullying dibagi menjadi tiga jenis (Coloroso, Barbara, 2007:47), yaitu:

\section{c. Bullying Fisik}

Penindasan fisik merupakan jenis bullying yang paling tampak dan paling dapat diidentifikasi diantara bentuk-bentuk penindasan lainnya, namun kejadian penindasan fisik terhitung kurang dari sepertiga insiden penindasan yang dilaporkan oleh siswa.

Jenis penindasan secara fisik di antaranya adalah memukul, mencekik, menyikut, meninju, menendang, menggigit, memiting, mencakar, serta meludahi anak yang ditindas hingga ke posisi yang menyakitkan, serta merusak dan menghancurkan pakaian serta barang-barang milik anak yang tertindas. Semakin kuat dan semakin 


\section{Konseling Behavioral: Solusi Alternatif Mengatasi Bullying ...}

dewasa sang penindas, semakin berbahaya jenis serangan ini, bahkan walaupun tidak dimaksudkan untuk mencederai secara serius.

\section{d. Bullying Verbal}

Kekerasan verbal adalah bentuk penindasan yang paling umum digunakan, baik oleh anak perempuan maupun anak laki-laki. Kekerasan verbal mudah dilakukan dan dapat dibisikkan dihadapan orang dewasa serta teman sebaya, tanpa terdeteksi. Penindasan verbal dapat diteriakkan di taman bermain bercampur dengan hingar binger yang terdengar oleh pengawas, diabaikan karena hanya dianggap sebagai dialog yang bodoh dan tidak simpatik di antara teman sebaya. Penindasan verbal dapat berupa julukan nama, celaan, fitnah, kritik kejam, penghinaan, dan pernyataan-pernyataan bernuansa ajakan seksual atau pelecehan seksual. Selain itu, penindasan verbal dapat berupa perampasan uang jajan atau barangbarang, telepon yang kasar, e-mail yang mengintimidasi, surat-surat kaleng yang berisi ancaman kekerasan, tuduhan-tuduhan yang tidak benar, kasak-kusuk yang keji, serta gosip.

\section{e. Bullying Relasional}

Jenis ini paling sulit dideteksi dari luar. Penindasan relasional adalah pelemahan harga diri si korban penindasan secara sistematis melalui pengabaian, pengucilan, pengecualian, atau penghindaran. Penghindaran, suatu tindakan penyingkiran, adalah alat penindasan yang terkuat. Anak yang digunjingkan mungkin akan tidak mendengar gosip itu, namun tetap akan mengalami efeknya. Penindasan relasional dapat digunakan untuk mengasingkan atau menolak seorang teman atau secara sengaja ditujukan untuk merusak persahabatan. Perilaku ini dapat mencakup sikap-sikap tersembunyi seperti pandangan yang agresif, lirikan mata, helaan napas, bahu yang bergidik, cibiran, tawa mengejek, dan bahasa tubuh yang kasar.

\section{f. Cyber bullying}

Ini adalah bentuk bullying yang terbaru karena semakin berkembangnya teknologi, internet dan media sosial. Pada intinya adalah korban terus menerus mendapatkan pesan negative dari pelaku bullying baik dari sms, pesan di internet dan media sosial lainnya Bentuknya berupa: a) Mengirim pesan yang menyakitkan atau menggunakan gambar; b) Meninggalkan pesan voicemail yang 
kejam; c) Menelepon terus menerus tanpa henti namun tidak mengatakan apa-apa (silent calls); d) Membuat website yang memalukan bagi si korban; e) Si korban dihindarkan atau dijauhi dari chat room dan lainnya; f) "Happy slapping" - yaitu video yang berisi dimana si korban dipermalukan atau di-bully lalu disebarluaskan

Sedangkan Riauskina, dkk mengelompokkan perilaku bullying ke dalam 5 kategori, yaitu: a) Kontak fisik langsung (memukul, mendorong, menggigit, menjambak, menendang, mengunci, seseorang dalam ruangan, mencubit, mencakar, juga termasuk memeras dan merusak barang-barang yang dimiliki orang lain); b) Kontak verbal langsung (mengancam, mempermalukan, merendahkan (put-down), mengganggu, member panggilan nama (name-calling), sarkasme, mencela/mengejek, memaki, menyebarkan gosip);

Sedangkan perilaku non verbal dibedakan menjadi dua yaitu: a) Perilaku non verbal langsung (melihat dengan sinis, menjulurkan lidah, menampilkan ekspresi muka yang merendahkan, mengejek, atau mengancam, biasanya disertai oleh bullying fisik atau verbal) ; dan b) Perilaku non verbal tidak langsung (mendiamkan seseorang, memanipulasi persahabatan sehingga retak, sengaja mengucilkan atau mengabaikan, mengirimkan surat kaleng); dan Pelecehan seksual (kadang-kadang dikategorikan perilaku agresi fisik atau verbal. 1

\section{Faktor penyebab terjadinya bullying}

Quiroz et al,. mengemukakan sedikitnya ada tiga faktor yang menyebabkan terjadinya perilaku bullying (Sugiharto, Indriani. 2009:20), yaitu:

\section{a. Hubungan keluarga}

Oliver et al., mengemukakan enam karakteristik faktor latar belakang dari keluarga yang memengaruhi perilaku bullying pada individu, yaitu sebagai berikut. Lingkungan emosional yang beku dan kaku dengan tidak adanya saling memperhatikan dan memberikan

\footnotetext{
${ }^{1}$ Riauskina, Duwita, \& Soesetio, “Gencet-Gencetan” Di Mata Siswa/SiswiKelas 1 SMA : Naskah Kognitif Tentang Arti Skenario dan Dampak "GencetGencetan". Jurnal Psikologi Sosial,Volume.12. Nomor.01, September, Fakultas Psikologi Universitas Indonesia,2005,hlm.20 (Artikel tidak ada)
} 


\section{Konseling Behavioral: Solusi Alternatif Mengatasi Bullying ...}

kasih sayang yang hangat; pola asuh yang permissive dengan pola asuh serba membolehkan, sedikit sekali memberikan aturan, membatasi untuk berperilaku, struktur keluarga yang kecil; Pengasingan keluarga dari masyarakat, kurangnya kepedulian terhadap hidup bermasyarakat, serta kurangnya keterlibatan keluarga dalam aktivitas bermasyarakat; konflik yang terjadi antara orangtua, dan ketidakharmonisan dalam keluarga; penggunaan disiplin, orangtua gagal untuk menghukum atau malah memperkuat perilaku agresi dan gagal untuk memberikan penghargaan; pola asuh orang tua yang otoriter dengan menggunakan kontrol dan hukuman sebagai bentuk disiplin yang tinggi, orang tua mencoba untuk membuat rumah tangga dengan aturan yang standar dan kaku (Sanders Cheryl E, and Phye Gary D 2004:123).

\section{b. Teman Sebaya}

Pada usia remaja, anak lebih banyak menghabiskan waktunya diluar rumah. Pada masanya remaja memiliki keinginan untuk tidak lagi terlalu bergantung pada keluarganya dan mulai mencari dukungan dan rasa aman dari kelompok sebayanya, oleh karena itu salah satu faktor yang sangat besar dari perilaku bullying pada remaja disebabkan oleh teman sebaya yang memberikan pengaruh negatif dengan cara memberikan ide baik secara aktif maupun pasif bahwa bullying tidak akan berdampak apa-apa dan merupakan suatu hal yang wajar dilakukan.

Pencarian identitas diri remaja dapat melalui penggabungan diri dalam kelompok teman sebaya atau kelompok yang diidolakannya. Bagi remaja, penerimaan kelompok penting karena mereka bisa berbagi rasa dan pengalaman dengan teman sebaya dan kelompoknya. Untuk dapat diterima dan merasa aman sepanjang saat-saat menjelang remaja dan sepanjang masa remaja mereka, anak- anak tidak hanya bergabung dengan kelompok-kelompok, mereka juga membentuk kelompok yang disebut klik. Klik memiliki kesamaan minat, nilai, kecakapan, dan selera. Hal ini memang baik namun ada pengecualian budaya sekolah yang menyuburkan dan menaikan sejumlah kelompok diatas kelompok lainnya, hal itu menyuburkan diskriminasi dan penindasan atau dalam bahasa lain perilaku bullying (Coloroso, Barbara, 2007:65). 


\section{c. Pengaruh Media}

Program televisi yang tidak mendidik akan meninggalkan jejak pada benak pemirsanya. Akan lebih berbahaya lagi jika tayangan yang mengandung unsur kekerasan ditonton anak-anak pra sekolah perilaku agresi yang dilakukan anak usia remaja sangat berhubungan dengan kebiasaannya dalam menonton tayangan di televisi. Hasil penelitian Saripah mengatakan bahwa pengaru media dalam perilaku bullying sangat menentukan, survey yang dilakukan kompas memperlihatkan bahwa 56, 9\% anak meniru adegan-adegan film yang ditontonnya mereka meniru gerakan (64\%) dan kata-kata sebanyak(43\%)(Saripah, Ipah, 2006:3).

Berdasarkan data tersebut dapat diketahui bahwa televisi memiliki peranan penting dalam pembentukan cara berfikir dan berperilaku. Hal ini tidak hanya terbatas pada media televisi saja, namun juga dalam semua bentuk media yang lain. Remaja yang terbiasa menonton kekerasan di media cenderung akan berperilaku agresif dan menggunakan agresi untuk menyelesaikan masalah. Alasan bullying disekolah saat ini semakin meluas salah satunya adalah karena sebagian besar korban enggan menceritakan pengalaman mereka kepada pihak yang mempunyai kekuatan untuk mengubah cara berfikir mereka dan menghentikan siklus bullying, yaitu pihak sekolah dan orangtua.

\section{Teori Konseling Behavioral}

Konseling Behavioral adalah salah satu dari teori-teori konseling yang ada pada saat ini. Konseling behavioral merupakan bentuk adaptasi dari aliran psikologi behavioristik, yang menekankan perhatiannya pada perilaku yang tampak. Pada hakikatnya konseling merupakan sebuah upaya pemberian bantuan dari seorang konselor kepada klien, bantuan di sini dalam pengertian sebagai upaya membantu orang lain agar ia mampu tumbuh ke arah yang dipilihnya sendiri, mampu memecahkan masalah yang dihadapinya dan mampu menghadapi krisis-krisis yang dialami dalam kehidupannya(Yusuf, Syamsu \& Juntika, Nurihsan. 2005:9).

Pengertian konseling tidak dapat dipisahkan dengan bimbingan karena keduanya merupakan sebuah keterkaitan. Muhamad Surya mengungkapkan bahwa konseling merupakan bagian inti dari kegiatan bimbingan secara keseluruhan dan lebih 
berkenaan dengan masalah individu secara Pribadi (Muhamad,Surya 1988:25). Juntika mengutip pengertian konseling dari ASCA (American School Conselor Assosiation) sebagai berikut: Konseling adalah hubungan tatap muka yang bersifat rahasia, penuh dengan sikap penerimaan dan pemberian kesempatan dari konselor kepada klien, konselor mempergunakan pengetahuan dan keterampilannya untuk membantu kliennya dalam mengatasi maslah masalahnya (Yusuf, Syamsu \& Juntika, Nurihsan. 2005:15). Sedangkan pengertian behavioral/ behaviorisme adalah satu pandangan teoritis yang beranggapan, bahwa persoalan psikologi adalah tingkah laku, tanpa mengaitkan konsepi-konsepsi mengenai kesadaran dan mentalitas(JP. Chaplin, 2002:54).

Aliran Behaviorisme ini berkembang pada mulanya di Rusia kemuadian diikuti perkembangannya di Amerika oleh JB. Watson (1878-1958). Dari pengertian konseling dan behaviorisme yang dipaparkan di atas kita dapat menarik kesimpulan bahwa yang dimaksud dengan konseling behavioral adalah sebuah proses konseling (bantuan) yang diberikan oleh konselor kepada klien dengan menggunakan pendekatan-pendekatan tingkah laku (behavioral), dalam hal pemecahan masalah-masalh yang dihadapi serta dalam penentuan arah kehidupan yang ingin dicapai oleh diri klien. Menurut Krumboltz \& Thoresen konseling behavioral adalah suatu proses membantu orang untuk belajar memecahkan masalah interpersonal, emosional, dan keputusan tertentu(Muhamad,Surya 1988:187).

\section{a. Konsep Dasar Teori Konseling Behavioral}

Konsep dasar dari behaviorisme adalah prediksi \& control atas perilaku manusia yang tampak. Muhamad Surya memaparkan bahwa dalam konsep behavioral, perilaku manusia merupakan hasil belajar, sehingga dapat diubah dengan memanipulasi dan mengkreasi kondisi-kondisi belajar. Pada dasarnya, proses konseling merupakan suatu penataan proses atau pengalaman belajar untukmembantu individu untuk mengubah perilakunya agar dapat memecahkan masalahnya. Hal yang paling mendasar dalam konseling behavioral adalah penggunaan konsep-konsep behaviorisme dalam pelaksanaan konseling, seperti konsepreinforcement, yang nerupakan bentuk adaptasi dari teori 
pengkondisian klasik Pavlov, dan pengkondisiaan operan dari Skinner. Menurut Muhammad Surya menyatakan bahwa ada tiga macam hal yang dapat memberi penguatan yaitu : 1). Positive reinforcer, 2).Negative reinforcer, 3).no consequence and natural stimuli (Muhamad,Surya 1988:186).

\section{b. Hakikat Manusia Dalam Konseling Behavioral}

Hakikat manusia dalam pandangan para behaviorist adalah fasif dan mekanistis, manusia dianggap sebagai sesuatu yang dapat dibentuk dan diprogram sesuai dengan keinginan lingkungan yang membentuknya. Lebih jelas lagi Muhamad Surya menjelaskan tentang hakikat manusia dalam pandangan teori behavioristi sebagai berikut: dalam teori ini menganggap manusia bersifat mekanistik atau merespon kepada lingkungan dengan control terbatas, hidup dalam alam deterministic dan sedikit peran aktifnya dalam memilih martabatnya. Manusia memulai kehidupnya dengan memberikan reaksi terhadap lingkungannya, dan interaksi ini menghasilkan polapola perilaku yang kemudian membentuk kepribadian. Perilaku seseorang ditentukan oleh banyak dan macamnya penguatan yang diterima dalam situasi hidupnya (Muhamad,Surya 1988:186). Dapat kita simpulkan dari anggapan teori ini bahwa perilaku manusia adalah efek dari lingkungan, pengaruh yang paling kuat maka itulah yang akan membentuk percaya diri individu.

\section{c. Hubungan Konselor -Klien}

Yang menjadi perhatian utama konselor behavioral adalah perilaku yang tampak, dengan alasan ini banyak asumsi yang berkembang tentang pola hubungan konselor-klien lebih manupulatif- mekanistik dan sangat tidak Pribadi, namun seperti dituturkan Rosjidan salah satu aspek yang essensial dalam terapi behavioral adalah proses penciptaan hubungan Pribadi yang baik. Untuk melihat hubungan konselor-klien dalam seting konseling behavioral dapat kita perhatikan dari proses konseling behavioral. Proses konseling behavioral yaitu sebuah proses membantu orang untuk belajar memecahkan masalah interpersonal,emosional, dan keputusan tertentu.Jika kita perhatikan lebih lanjut, pendekatan dalam konseling behavioral lebih cenderung direktif, karena dalam 


\section{Konseling Behavioral: Solusi Alternatif Mengatasi Bullying ...}

pelaksanaannya konselor-lah yang lebih banyak berperan (Rosjidan 1988:243).

Peran Konselor diantaranya a) Menyebutkan tingkah laku mal-adaptip; b) Memilih tujuan-tujuan yang masuk akal; c) Mengarahkan dan membimbing keluarga untuk merubah tingkah laku yang tak sesuai. Sedangkan Penerapan teori tingkah laku ke dalam konseling Bullying anak menekankan 3 hal pokok yaitu; a) Menciptakan konseling yang positif; b) Mendiagnosis problemproblem Bullying ke dalam istilah tingkah laku; c) Mengimplementasikan prinsip-rinsip tingkah laku dari penguat dan model; d) Penggunaan model dan permainan peranan dalam proses penyembuhan dan e) Adanya kesepakatan atas hal yang akan diubah antara konselor dan pelaku Bullying

\section{d. Alternatif solusi mengatasi Bullying anak di sekolah}

Alternatif solusi untuk mengatasi bullying anak di sekolah adalah: Pertama, di lingkungan sekolah harus dibangun kesadaran dan pemahaman tentang bullying dan dampaknya kepada semua stakeholder di sekolah, mulai dari murid, guru, kepala sekolah, pegawai sekolah hingga orangtua. Sosialisasi tentang program anti bullying perlu dilakukan dalam tahap ini sehingga semua stakeholder memahami dan mengerti apa itu bullying dan dampaknya.

Kemudian kedua, harus dibangun sistem atau mekanisme untuk mencegah dan menangani kasus bullying di sekolah. Dalam tahap ini perlu dikembangkan aturan sekolah atau kode etik sekolah yang mendukung lingkungan sekolah yang aman dan nyaman bagi semua anak dan mengurangi terjadinya bullying serta sistem penanganan korban bullying di setiap sekolah. Sistem ini akan mengakomodir bagaimana seorang anak yang menjadi korban bullying bisa melaporkan kejadian yang dialaminya tanpa rasa takut atau malu, lalu penanganan bagi korban bullying, dll. Tidak kalah pentingnya adalah menghentikan praktek-praktek kekerasan di sekolah dan di rumah yang mendukung terjadinya bullying seperti pola pendidikan yang ramah anak dengan penerapan positive discipline di rumah dan di sekolah. Langkah ini membutuhkan komitmen yang kuat dari guru dan orangtua untuk menghentikan praktek-praktek kekerasan dalam mendidik anak. Pelatihan tentang metode positif disiplin perlu dilakukan kepada guru dan orangtua 
dalam tahap ini. Terakhir adalah membangun kapasitas anak-anak kita dalam hal melindungi dirinya dari pelaku bullying dan tidak menjadi pelaku. Untuk itu anak-anak bisa diikutkan dalam pelatihan anti Bullying serta berpartisipasi aktif dalam kampanye anti bullying di sekolah. Dalam tahap ini metode dari anak untuk anak (child to child) dapat diterapkan dalam kampanye dan pelatihan.

Ketiga, diharapkan pemerintah dalam hal ini Dinas Pendidikan memberikan perhatianter hadap isu bullying di sekolah serta berupaya membangun kapasitas aparaturnya dalam mengatasi isu ini. Langkah strategis yang perlu diambil adalah memasukkan isu ini kedalam materi pelatihan guru serta mengembangkan program anti bullying di tiap sekolah. Dalam kasus tertentu bullying bisa bersentuhan dengan aspek hukum, maka melibatkan aparat penegak hukum dalam program anti bullying akan sangat efektif.

\section{Mengatasi Bullying Anak Melalui Konseling Behavior}

Selama ini beberapa upaya telah dilakukan oleh sekolah bagi pelaku pelaku bullying, yaitu pemberian hukuman sanksi dan panggilan orang tua ke sekolah untuk bekerja sama memberikan penanganan. Sejauh ini hasil yang dicapai belum maksimal, karena perubahan sikap dan perilaku pelaku bullying hanya sementara. Karena mereka kembali mengulang perbuatannya dilain hari. Alternatif solusi untuk mengatasi masalah bullying anak di sekolah salah satunya dengan konseling behavioral. Konseling behavioral adalah suatu proses membantu orang untuk belajar memecahkan masalah interpersonal, emosional dan kepentingan tertentu". Penekanan istilah belajar dalam pengertian ini ialah atas pertimbangan bahwa konselor membantu orang (konseli) belajar atau mengubah perilaku. Konselor berperan membantu dalam proses belajar menciptakan konvisi yang sedemikian rupa sehingga klien dapat mengubah perilakunya serta memecahkan masalahnya. Penggunaan konseling behavioral sebagai alternatif pemecahan masalah, menurut penulis karena mengingat konseling behavioral memiliki konsep-konsep dasar sebagai berikut : a) Manusia adalah makhluk reaktif yang tingkah lakunya dikontrol oleh faktor-faktor dari luar. Manusia memulai kehidupan dengan memberikan reaksi terhadap lingkungannya dan interaksi ini menghasilkan pola-pola perilaku yang kemudian membentuk kepribadian. b) Tingkah laku 


\section{Konseling Behavioral: Solusi Alternatif Mengatasi Bullying ...}

seseorang ditentukan oleh banyak dan macamnya penguatan yang diterima dalam situasi hidupnya; c) Tingkah laku dipelajari ketika individu berinteraksi dengan lingkungan melalui hukum-hukum belajar (pembiasaan klasik, pembiasaan operan dan peniruan); d) Tingkah laku tertentu pada individu dipengaruhi oleh kepuasan dan ketidakpuasan yang diperolehnya; e) Manusia bukanlah hasil dari dorongan tidak sadar melainkan merupakan hasil belajar, sehingga ia dapat diubah dengan memanipulasi dan mengkreasi kondisi- kondisi pembentuk tingkah laku.

Dengan melihat keunggulan konseling behavioral tersebut diatas, penulis berharap dapat meminimalisir pelaku bullying di institusi sekolah, sehingga sekolah dapat menjadi tempat belajar yang aman, menyenangkan, merangsang keinginan untuk belajar, bersosialisasi dan mengembangkan semua potensi siswa baik akademik, sosial maupun emosional

\section{F. Simpulan}

Masalah bullying di sekolah adalah tanggung jawab semua pihak yang ada di sekolah dan orang tua siswa. Kegiatan bullying di sekolah merupakan satu masalah besar yang harus diatasi karena seharusnya sekolah melindungi siswanya dari tindakan kekerasan dalam bentuk apapun, dan menjadi wadah untuk pembentukan akal, moral dan karakter yang diperlukan untuk membangun masyarakat Indonesia yang sehat, berbudaya dan berteknologi tinggi. Bullying ini bisa dicegah selama semua yang terkait dalam institusi tersebut memiliki andil dan kepedulian untuk mengubah dan mencegah persoalan tersebut.Konseling behavioral merupakan adaptasi dari aliran psikologi behaviorisme yang memfokuskan perhatiannya pada tingkah laku yang tampak. Banyak pendekatan dalam konseling behavioral, dari keseluruhan pendekatan yang ada semua menjurus pada pendekatan direktif dimana konselor lebih berperan aktif dalam pengangan masalahnya. 


\section{Daftar Pustaka}

Astuti, R.P. 2008. Meredam Bullying (3 Cara Efektif Mengatasi Kekerasan Pada Anak). Jakarta: PT. Grasindo.

Bimo. Walgito, 2002. Pengantar Psikologi. Yogyakarta : Penerbit Andi Latipun, 2003. Psikologi Konseling, Malang: UMM Press

Coloroso, Barbara, 2007. Stop Bullying (Memutus Rantai Kekerasan

Anak Dari Prasekolah Hingga SMU). Jakarta: PT. Ikrar Mandiri abadi.

Davit Setyawan. 2017. KPAI Terima Aduan 26 Ribu Kasus Bully Selama 2011-2017. Http://Www.Kpai.Go.Id. http://www.kpai.go.id/berita/kpai-terima-aduan-26-ribukasus-bully-selama-2011-2017.

JP. Chaplin, 2002. Kamus Lengkap Psikologi (Terj. Kartono, Kartini). Jakarta: Raja Grapindo.

Latipun, 2003. Psikologi Konseling. Malang: UMM Press.

Muhamad, Surya. 1988. Dasar-Dasar Konseling Pendidikan

(Teori\&Konsep). Yogyakarta: Penerbit Kota Kembang.

Ponny Retno Astuti, 2008. Meredam Bulliying: 3 Cara Efektif Mengatasi Kekerasan Pada Anak.

Rosjidan. 1988. Pengantar Teori-Teori Konseling. Jakarta:

Departemen Pendidikan dan Kebudayaan: Dirjen DIKTI.

Sanders Cheryl E, and Phye Gary D. 2004 Bullying : Implications for the Classroom. California USA: Elsevier Academic Press.

Saripah, Ipah, 2006. "Program Bimbingan Untuk Mengembangkan Perilaku Proposional Anak." UPI Bandung.

Sejiwa. 2008. Bullying: Mengatasi Kekerasan Di Sekolah Dan Lingkungan Sekitar Anak. Jakarta: Grasindo.

Sigit Kurniawan 2017 Siswa SD Di Gebog, Kudus Jadi Korban Bullying. Https://Elshinta.Com. diakses dari http://m.elshinta.com/news/115775/2017/07/31/siswa-sddi-gebog-kudus-jadi-korban-bulliying.

Sugiharto, Indriani. 2009. Layanan Responsif Bimbingan Dan Konseling Berbasis Model Transteori Untuk Menanggulangi Perilaku Bullying Siswa. Universitas Pendidikan Indonesia (UPI) Bandung. 
Konseling Behavioral: Solusi Alternatif Mengatasi Bullying ...

Sullivan, 2002. The Anti-Bulliying Handbook. Oxford: Oxford University Press.

Yusuf, Syamsu \& Juntika, Nurihsan. 2005. Landasan Bimbingan Dan Konseling. Bandung: Rosdakaraya. 